\title{
Expression of hepatic genes related to energy metabolism during the transition period of Holstein and $F_{1}$ Holstein-Gir cows
}

\author{
J. G. Laguna, ${ }^{*}$ M. S. Cardoso,† J. A. Lima, ${ }^{*}$ R. B. Reis, ${ }^{*}$ A. U. Carvalho,‡ H. M. Saturnino, ${ }^{* 1}$ \\ and S. M. R. Teixeira $\S^{1}$ \\ *Department of Animal Science, Federal University of Minas Gerais (UFMG), Belo Horizonte, Minas Gerais, 30161-970, Brazil \\ †Department of Parasitology, UFMG, Belo Horizonte, 31270-901, Brazil \\ ‡Department of Clinical and Surgery, UFMG, Belo Horizonte, 30161-970, Brazil \\ §Biochemistry and Immunology Department, UFMG, Belo Horizonte, 31270-901, Brazil
}

\begin{abstract}
The aim of this study was to investigate the expression of genes encoding enzymes and other factors involved with carbohydrate and lipid metabolism in the liver of 2 genetic groups of dairy cows during the transition period. We analyzed the expression of glucose6-phosphatase $(G 6 P C)$, cytosolic phosphoenolpyruvate carboxykinase (PEPCK-C), methylmalonyl-CoA mutase $(M U T), \quad \beta$-hydroxybutyrate dehydrogenase-2 $(B D H 2)$, acetyl-CoA carboxylase $(A C C)$, carnitine palmitoyltransferase-2 (CPT2), 3-hydroxy-3-methylglutaryl-CoA reductase (HMGCR), glucose transporter-2 (SLC2A2), and the transcription factor peroxisome proliferator-activated receptor $\alpha(P P A R A)$. Blood concentrations of glucose, nonesterified fatty acids , and $\beta$-hydroxybutyrate were also determined. Liver biopsies and blood samples were taken at d 15 prepartum and at d 6, 21, 36, 51, and 66 postpartum from Holsteins $(\mathrm{n}=6)$ and $\mathrm{F}_{1}$ Holstein-Gir $(\mathrm{n}=6)$ cows. Cows were kept under the same prepartum and postpartum management conditions. The results showed that the expression of $G 6 P C, P E P C K-C, B D H 2, A C C$, CPT2, HMGCR, SLC2A2, and PPARA genes did not differ between genetic groups. Except for PEPCK-C, no interaction between genetic groups and the experimental period was observed. Within both groups of cows, G6PC and PEPCK-C gene expression decreased when comparing prepartum gene expression with 21 and 36 DIM, and increased in d 51 postpartum. MUT mRNA levels differed between the 2 genetic groups and displayed a significant increase after d 36 postpartum, whereas mRNA levels of $H M G C R$ tended to increase
\end{abstract}

Received December 14, 2016.

Accepted August 11, 2017. br when comparing d 21 and 36 to d 51 postpartum. Glucose concentrations also differed between genetic groups, being significantly higher in the plasma of $F_{1}$ Holstein-Gir cows than in Holstein cows, but no differences were found within each group during the analysis period. $\beta$-Hydroxybutyrate and nonesterified fatty acid concentrations did not differ between genetic groups, but displayed increased levels from prepartum to d 6 and 21 postpartum. Our results indicated that expression in the liver of genes involved with glucose and fatty acid metabolism were similar in both groups of cows and significant differences were observed between the 2 groups in the expression of MUT, a gene involved in propionate metabolism.

Key words: gene expression, genetic group, energy metabolism, Holstein, $\mathrm{F}_{1}$ Holstein-Gir

\section{INTRODUCTION}

During the transition period, important physiological, immunological, and metabolic changes can affect various physiological processes linked to lactation performance and postpartum diseases (Goff and Horst, 1997; van Dorland et al., 2009). This period is marked by increased energetic requirements due to development of the fetus and synthesis of milk (Bell, 1995). In the early postpartum, the nutritional demands exceed the intake capacity of the dairy cow, leading to a status of negative energy balance (NEB). In Holstein cows, plasma concentrations of glucose and insulin decrease around calving (Grummer, 1995; Mann et al., 2016). A significant decrease in plasma glucose concentrations $2 \mathrm{~d}$ after calving has also been observed in $\mathrm{F}_{1}$ Holstein-Gir cows, a genetic group that accounts for $70 \%$ of dairy cattle in Brazil (Moreira et al., 2015). In contrast, plasma concentrations of nonesterified fatty acid (NEFA) and ketone bodies, like BHB, increase in Holstein cows (Doepel et al., 2002; van Dorland et al., 2009) and in $F_{1}$ Holstein-Gir cows around calving 
(Moreira et al., 2015). Increased demand for energy leads to an increased mobilization of body reserves, possibly in response to the NEB state, leading to an increased use of NEFA and ketone bodies as energy sources (Grummer, 1993; Drackley, 1999).

During the postpartum period, there is an increased flux of NEFA into the liver to be oxidized and/or converted to ketone bodies and triglycerides. Due the limited capacity of the liver to export triglycerides via low-density lipoproteins, especially during early lactation (Bobe et al., 2004), triglyceride accumulation in hepatocytes may occur, which can alter the liver structure and function (Reid and Collins, 1980; Grummer, 1993) leading to fatty liver and ketosis disease. This disorder is associated with decreased health status and milk productivity of cows (Bobe et al., 2004). Increased levels of NEFA and BHB may affect metabolic regulation in the liver, which plays a central role during the transition period, when the main necessity of a cow is a successful metabolic adaptation, without the occurrence of health disorders (Graber et al., 2010).

Recently, several studies aimed at characterizing the expression profile of genes related to carbohydrate and lipid metabolism in the liver of cows consuming the same diet (van Dorland et al., 2009; Graber et al., 2010), or different types of diet during the transition period (Zhang et al., 2015; White et al., 2016), as well as with different genetic groups of cows (White et al., 2011; Alam et al., 2012), have been described. Also, the negative effects of severe NEB and high BHB plasma concentrations on hepatic gluconeogenesis and lipogenesis (Loor et al., 2007; McCarthy et al., 2010; Weber et al., 2013a) have been examined. One of these studies indicated that the expression of the pyruvate carboxylate $(P C)$ gene can be regulated by NEFA through either activation or suppression of its unique promoter (White et al., 2011).

To our knowledge, no comparative studies are available investigating gene expression related to carbohydrate or lipid metabolism in Holstein and $\mathrm{F}_{1}$ HolsteinGir cows. The $\mathrm{F}_{1}$ Holstein-Gir is a crossbred (Bos taurus taurus $\times$ Bos taurus indicus) highly adapted to management under tropical conditions in Brazil. Being adapted to heat and having developed parasite resistance, $\mathrm{F}_{1}$ Holstein-Gir cows have improved milk-protein and fat percentages, as well as increased fertility compared with other dairy breeds raised under Brazilian environment and management conditions (Santos et al., 2012; Alves et al., 2014). Therefore, the present study had the objective of investigating changes in the concentrations of glucose, NEFA, and BHB during the transition period of Holstein and $\mathrm{F}_{1}$ Holstein-Gir cows, as well as in the expression of several genes related to the glucose and fatty acid metabolism in the liver of these 2 genetic groups of dairy cows.

\section{MATERIALS AND METHODS}

\section{Animals, Management, and Diet}

Multiparous Holstein $(\mathrm{n}=6)$ and $\mathrm{F}_{1}$ Holstein-Gir $(\mathrm{n}=6)$ dairy cows were used. The experimental design and procedure were conducted at Experimental Hélio Barbosa farm, located in Igarapé, Minas Gerais, Brazil. Protocols for this study were approved by the ethics committee (Comissão de Ética no uso de Animais, UFMG), under protocol $77 / 2013$. At $30 \mathrm{~d}$ from estimated calving date, the cows of both genetic groups were transferred to prepartum pasture where they had access ad libitum to corn silage mixed with $2 \mathrm{~kg}$ of concentrate per cow, with this concentrate based on ground corn and soybean meal and minerals, to have 5 to $10 \%$ left over. At d 15 from estimated calving date, the cows were separated from the prepartum group and guided to a squeeze chute, in which blood and liver tissue sampling occurred. Then, the cows returned to prepartum pasture up to calving day. The prepartum pasture was close to the handling facility. After calving, the cows were conducted to handling facility for postpartum management (calf/colostrum) and the cows were then guided to the starting lactation group, in which they received corn silage ad libitum $(\mathrm{DM}=$ $34.51 \%, \mathrm{CP}=6.2 \%, \mathrm{NDF}=62.14 \%, \mathrm{ADF}=34.48 \%$ ), managed to have 5 to $10 \%$ left over in a common feeder, with ad libitum access to water. These cows were in a semi-intensive system, milked twice per day (0600 and $1500 \mathrm{~h}$ ). After milking, the cows were separated and conducted to the head gate feeder, where it was individually offered the concentrate (ground corn, soybean meal, urea, mineral mix, and sodium bicarbonate $\mathrm{DM}=92.42 \%, \mathrm{CP}=29.46 \%, \mathrm{NDF}=9.11 \%, \mathrm{ADF}=$ $6.46 \%, \mathrm{NFC}=49.77 \%, \mathrm{TDN}=78.31 \%, \mathrm{NE}_{\mathrm{L}}=1.94$ $\mathrm{Mcal} / \mathrm{kg}$, ash $=8.96 \%, \mathrm{Ca}=1.26 \%, \mathrm{P}=0.77 \%$ ), and the amount offered was based initially according to the peak milk production of the previous lactation and then according to the milk production of each cow. All cows consumed the same diet components; however, the amount of total diet consumed was not evaluated. Silage samples were withdrawn from different points of the silo during the experimental period and storage at $-20^{\circ} \mathrm{C}$. Samples of concentrate were withdrawn weekly and sent to bromatological analysis. Samples of silage and concentrate were analyzed in a commercial laboratory (3Rlab, Laboratory Chemical Analysis, Belo Horizonte, Minas Gerais, Brazil). Corn silage and concentrate were analyzed for DM, CP, Ca, P, and ash 
according to AOAC (1990). The NDF and ADF were analyzed through sequential method of Van Soest et al. (1991), and TDN, NFC, and $\mathrm{NE}_{\mathrm{L}}$ were determined according to NRC (2001).

Milk production was recorded at each milking for each cow individually. Samples were taken, after homogenization, using milk meters (Milk Meter-Mark V, Westfalia, Belo Horizonte, Brazil) at d 11, 25, 39, 53, and 67 postpartum. All procedures are described in the Supplemental Material (https://doi.org/10.3168/jds .2016-12459).

\section{Blood Collection and Analyses of Plasma Metabolites}

Blood samples were collected from the jugular vein at d 15 before the estimated calving and at d 6, 21, 36,51 , and 66 postpartum, after the morning milking and minutes before liver biopsy procedure. Each animal was guided to a squeeze chute, where blood samples were collected. After these procedures, the cows were conducted to the head gate feeder for individual consumption of concentrate. Corn silage was consumed in groups, as described above. Blood samples were taken by using evacuated tubes containing sodium heparin for the glucose dosage and tri-potassium-EDTA for NEFA and BHB analysis. Blood samples were immediately cooled and centrifuged for $15 \mathrm{~min}$ at $3,500 \times g$ at room temperature, and plasma was stored at $-20^{\circ} \mathrm{C}$. Commercial kits were used to determine the concentrations of glucose (enzymatic colorimetric, Kovalent), NEFA, and BHB (D-3-Hydroxybutyrate, Randox Laboratories Ltd., Ardmore, UK).

\section{Liver Tissue Collection, mRNA Extraction, and Quantitative Real-Time Reverse- Transcription PCR}

Liver samples were obtained through blind percutaneous needle biopsy (Tru-Cut semi-automatic biopsy needle, ProMedical, Juiz de Fora, Minas Gerais, Brazil) under local anesthesia in the same days of blood sampling. Liver tissues (70-150 mg) were placed directly into RNA stabilization reagent (RNAlater, Ambion, Applied Biosystems, Waltham, MA; Kreipe et al., 2011) and thereafter stored at $-80^{\circ} \mathrm{C}$. Total RNA was isolated from liver samples using Direct-Zol MiniPrep kit (Zymo Research, Irvine, CA) according to the manufacturer's protocol, and afterward quantity and purity were determined by absorbance at 260 and 280 nm using a NanoDrop ND-2000 spectrophotometer (NanoDrop Technologies, Wilmington, DE), where 260/280 absorption ratio was between 2.0 and 2.2 for all samples. The integrity of total RNA was verified by the presence of $28 \mathrm{~S}$ and $18 \mathrm{~S}$ rRNA bands that were visualized after electrophoretic separation in $2 \%$ agarose gels. The total RNA was treated with DNase using NucleoSpin RNA kit (Macherey-Nagel), according to the manufacturer's protocol. For reverse transcription, $1 \mu \mathrm{g}$ of extracted total RNA was reverse transcribed with $200 \mathrm{U}$ of Moloney murine leucemia virus reserve transcriptase RNase H minus (SuperScript II, Invitrogen, Carlsbad, CA), using oligonucleotide deoxythymidine $\left[\right.$ Oligo $\left.(\mathrm{dT})_{18}, 0.5 \mu \mathrm{g} / \mu \mathrm{L}\right]$. The obtained $\mathrm{cDNA}$ was diluted to a final concentration of $25 \mathrm{ng} / \mu \mathrm{L}$. Negative control samples were prepared by including all reagents as above for the cDNA synthesis, minus the reverse transcriptase enzyme to ensure no genomic DNA contamination occurred. The gene-specific primers $M U T$, PEPCK-C, CPT2, and SLC2A2 were designed online using the Primer-BLAST software program (http:// www.ncbi.nlm.nih.gov/tools/primer-blast/) and GAP$D H$ and $A C T B$ from Hammon et al. (2003) and RPS9, G6PC, BDH2, ACC, HMGCR, and PPARA from Graber et al. (2010; Table 1). All oligonucleotides were commercially synthesized (Life Technologies, Carlsbad, CA). For each sample, PCR conditions were optimized by conventional PCR amplification using GoTaq DNA polymerase (Promega, Madison, WI), with the addition of $1 \mu \mathrm{L}$ of cDNA $(25 \mathrm{ng} / \mu \mathrm{L})$ and $0.5 \mu M$ forward and reverse primer mix. Real-time PCR analyses were performed using the ABI 7900 real time PCR System (Applied Biosystems), using Sequence Detection Software (SDS) v2.4 (Applied Biosystems). One microliter of each sample containing $25 \mathrm{ng}$ of cDNA was amplified to $10 \mu \mathrm{L}$ with $5 \mu \mathrm{L}$ of Platinum Syber Green qPCR SuperMix-UDG with ROX (Invitrogen), $0.2 \mu M$ primers (forward and reverse), and $3 \mu \mathrm{L}$ of nuclease-free water. The following 3-step PCR program was used: denaturation for $10 \mathrm{~min}$ at $95^{\circ} \mathrm{C}, 40$ cycles of amplification (each consisting of $15 \mathrm{~s}$ at $95^{\circ} \mathrm{C}$, the primer-specific annealing temperature and extension at $60^{\circ} \mathrm{C}$ for $1 \mathrm{~min}$, and quantification of fluorescence), and finally a melting curve program $\left(60-95^{\circ} \mathrm{C}\right)$. The efficiency calculation and percentage relative mRNA abundance can be found in Supplemental Table S2 (https://doi.org/10 .3168/jds.2016-12459). The gene expression levels were calculated relative to the average mRNA levels of 3 housekeeping RPS9, GAPDH, and $A C T B$, according to Graber et al. (2010).

\section{Statistical Analysis}

Data are presented as adjusted means \pm SEM. The experimental design was completely randomized. Variables related to glucose, NEFA, and BHB and G6PC, 
PEPCK-C, MUT, SLC2A2 (Glut2), ACC, PPARA, CPT2, HMGCR, and BDH2 genes were analyzed using mixed linear models (PROC MIXED, SAS, version 9.1, SAS Institute Inc., Cary, NC) considering as fixed effects genetic group, period, and as random effects of the animal. Each individual cow served as experimental unit. For each analysis, the model included genetic group (Holstein and $\mathrm{F}_{1}$ Holstein-Gir), period and the interaction between them (group $\times$ period). The repeated subject was the individual cow. The significance of differences between the genetic groups and among periods were analyzed using the Tukey-Kramer test and considered significant when $P \leq 0.05$.

The statistical model used was

$$
Y_{i j k}=\mu+g_{i}+\operatorname{per}_{j}+g \times \operatorname{per}_{i j}+a_{k}+e_{i j k},
$$

where $Y_{i j k}=$ the $i j k t h$ observation response; $\mu=\mathrm{a}$ mean, constant common to all observations; $g=$ genetic $\operatorname{group}_{i} ;$ per $=\operatorname{period}_{j} ; g \times$ per $=$ interaction genetic $\operatorname{group} \times \operatorname{period}_{i j} ; a_{k}=$ random effect of animal $_{k} ;$ and $e_{i j k}=$ random residual term from a normal distribution.

\section{RESULTS AND DISCUSSION}

\section{Production, Composition of Milk, and Plasma Metabolic Profiles}

The overall average of milk production of Holstein cows $(28.46 \mathrm{~kg})$ differed from $\mathrm{F}_{1}$ Holstein-Gir cows (24.19 kg; $P=0.0360$; Supplemental Table S1, https:// doi.org/10.3168/jds.2016-12459), but did not differ during the experimental period within each genetic group $(P=0.6979$; Supplemental Table S1, https:// doi.org/10.3168/jds.2016-12459). Also, no interaction was observed between genetic groups and the experimental period. Regarding milk composition, fat and protein percentages were higher in $\mathrm{F}_{1}$ Holstein-Gir than in Holstein cows $(P<0.05)$. Interaction between genetic group and experimental period was observed only for fat content $(P=0.0105)$. Protein content differed throughout the experimental period $(P=0.0174)$ in both groups. Lactose did not differ between genetic groups or throughout the experimental period (Supplemental Table S1; https://doi.org/10.3168/jds.2016 -12459). The transition period is the biggest metabolic

Table 1. Sequence of primers used in real-time PCR reactions, the number of GenBank accession/European Molecular Biology Laboratory (EMBL), and the number of base pairs of PCR products

\begin{tabular}{|c|c|c|c|c|}
\hline Gene $^{1}$ & & Sequence $5^{\prime}-3^{\prime}$ & $\begin{array}{l}\text { Accession no. } \\
\text { GenBank/EMBL }\end{array}$ & Product size (bp) \\
\hline \multirow[t]{2}{*}{ GAPDH } & $\mathrm{F}$ & GTCTTCACTACCATGGAGAAGG & U85042 & 197 \\
\hline & $\mathrm{R}$ & TCATGGATGACCTTGGCCAG & & \\
\hline \multirow[t]{2}{*}{$A C T B$} & $\mathrm{~F}$ & CAGGATGCAGAAAGAGATCACTGC & NM_173979.3 & 222 \\
\hline & $\mathrm{R}$ & AGGGTGTAACGCAGCTAACAG & & \\
\hline \multirow[t]{2}{*}{$R P S 9$} & $\mathrm{~F}$ & AAGCTGATCGGCGAGTATG & NM_001101152 & 140 \\
\hline & $\mathrm{R}$ & GCATTACCTTCGAACAGACG & & \\
\hline \multirow[t]{2}{*}{$G 6 P C$} & $\mathrm{~F}$ & GCCAACCTACAGATTTCGGTG & NM_001076124 & 140 \\
\hline & $\mathrm{R}$ & CAATGCCTGACAAGACTCCAG & & \\
\hline \multirow[t]{2}{*}{$P E P C K-C$} & $\mathrm{~F}$ & ATGACAACTGCTGGTTGGCT & NM_174737 & 123 \\
\hline & $\mathrm{R}$ & GCTGACTGAGGCCGTTTTTG & & \\
\hline \multirow{2}{*}{$M U T$} & $\mathrm{~F}$ & GGGATTCCCAAAGTGGCTGA & NM_173939.2 & 177 \\
\hline & $\mathrm{R}$ & TCTTCGGGCAGCACATTCTT & & \\
\hline \multirow[t]{2}{*}{ BDH2 } & $\mathrm{F}$ & TGCAACTGTGTGTGTCCAG & NM_001034488 & 175 \\
\hline & $\mathrm{R}$ & CAGATTCATCAGAGGCCAAG & & \\
\hline \multirow[t]{2}{*}{$A C C$} & $\mathrm{~F}$ & CTCTTCCGACAGGTTCAAGC & AJ_132890 & 248 \\
\hline & $\mathrm{R}$ & ACCATCCTGGCAAGTTTCAC & & \\
\hline \multirow[t]{2}{*}{ CPT2 } & $\mathrm{F}$ & ATCGTGCCCACTATGCACT & BC-105423 & 128 \\
\hline & $\mathrm{R}$ & TCTGTTTTCCTGAACTGGCTGT & & \\
\hline \multirow[t]{2}{*}{$H M G C R$} & $\mathrm{~F}$ & ACCCATGAGCGAGGTGTATC & BC153262 & 241 \\
\hline & $\mathrm{R}$ & TAGTGCTGGCCACAAGACAG & & \\
\hline \multirow[t]{2}{*}{$S L C 2 A 2$} & $\mathrm{~F}$ & ACAAGCCTGGGAGATCCAAC & NM_001103222.1 & 147 \\
\hline & $\mathrm{R}$ & CCCAAGCAACCCTCCAAAGA & & \\
\hline \multirow[t]{2}{*}{ PPARA } & $\mathrm{F}$ & AGGGCTGCAAGGGTTTCTTTAG & NM_001034036 & 363 \\
\hline & $\mathrm{R}$ & TGACGAAAGGCGGGTTGTTGTTG & & \\
\hline
\end{tabular}

${ }^{1} A C T B=\beta$-actin; $R P S 9=$ ribosomal protein S9; $G 6 P C=$ glucose-6-phosphatase; $P E P C K-C=$ cytosolic phosphoenolpyruvate carboxykinase; $M U T=$ methylmalonyl-CoA mutase; $B D H 2=\beta$-hydroxybutyrate dehydrogenase-2; $A C C=$ acetyl-CoA-carboxylase; $C P T 2=$ carnitine palmitoyltransferase- $2 ; H M G C R=3$-hydroxy3-methylglutaryl-CoA reductase; SLC2A2 = glucose transporter-2 (Glut2); PPARA = peroxisome proliferatoractivated receptor $\alpha . F=$ forward; $\mathrm{R}=$ reverse. 
challenge faced by dairy cows, mainly because of the requirement of increased energy to keep up with increasing milk production. The production and composition of milk depend on the parity and genotype of the cows, and these characteristic may interact with dietary supply of nutrients. As shown in several studies, cows with different genotypes may show different responses in milk production and composition (Hansen et al., 2006; Fulkerson et al., 2008).

The plasma concentration of glucose differed between genetic group $(P<0.05$; Table 2$)$, being significantly higher in the plasma of $F_{1}$ Holstein-Gir cows than in Holstein cows; however, plasma glucose concentrations did not differ during the experimental period within each genetic group and there was no interaction between genetic groups and the experimental period (Table 2). In contrast to our results, Graber et al. (2010) and Weber et al. (2013b) observed a decrease in plasma glucose concentrations in Holstein cows after calving. Other studies, such as the one described by Sofyan et al. (2017), showed no significant differences in plasma glucose levels before and after parturition in Holstein dairy cows. Plasma concentrations of NEFA and BHB did not differ between genetic groups and there was no interaction between genetic groups and experimental period $(P>0.05$; Table 2$)$. However, in both groups of cows, the average values for NEFA and BHB plasma concentrations were significantly higher at d 6 and 21 when compared with d 15 prepartum and all other postpartum days analyzed $(P<0.05$; Table 2$)$. Similar results regarding the changes of NEFA and BHB plasma concentrations, which indicate changes in the metabolic state over the studied period, were observed by van Dorland et al. (2009) and Weber et al. (2013b). During the transition period, various hormonal and metabolic alterations affect the physiological state of a cow, leading to gradual adjustments of this complex system in a way that may vary considerably between cows (van Dorland et al., 2009). After calving, dairy cows enter a state of NEB (Bauman and Currie 1980), and yet both concentrations of NEFA and BHB may increase due to rapid mobilization of the body fat (Emery et al., 1992). The NEFA released from adipose tissue can be fully oxidized to $\mathrm{CO}_{2}$ or partly converted to ketone bodies (acetoacetate or BHB) or esterified into triglycerides, which can be stored in the hepatocyte or released into blood as very low density lipoproteins (VLDL). However, export of triglycerides via VLDL is inefficient in ruminants due to reduced mRNA and protein levels of apolipoprotein $\mathrm{B}$, the main protein present in VLDL (Loor, 2010). The increase of BHB concentration is due to increased uptake of fatty acids by the liver and acetyl-CoA production, from fatty acid oxidation, which exceeds its utilization by the citric

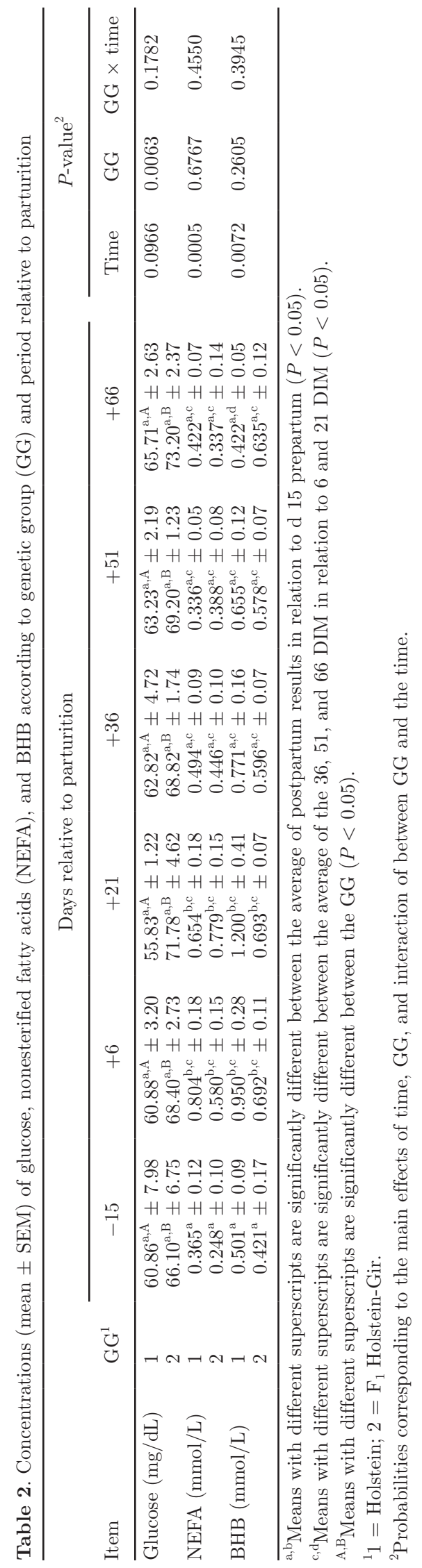

Journal of Dairy Science Vol. 100 No. 12, 2017 
acid cycle or lipogenesis (Bergman, 1971; Duffield et al., 2008). In our studies, the BHB concentrations were higher than $0.75 \mathrm{mmol} / \mathrm{L}$, which was considered by van Dorland et al. (2009) as an indication of an enhanced ketogenesis and a large energy deficit during the first weeks of lactation.

\section{Liver Gene Expression Related to Glucose Metabolism}

Within both groups of cows, mRNA levels of the G6PC gene at 21 and 36 DIM were lower than at prepartum levels and increased levels were observed at d 51 postpartum as compared with prepartum levels $(P<0.05$, Figure 1A). The mRNA levels of the $P E P C K-C$ gene were also similar in both genetic groups, being higher during pre-calving compared with 21 and 36 DIM and increased in d 51 postpartum $(P<0.05$, Figure 1B). Expression analysis of the $M U T$ gene showed reduced mRNA levels at 21 and 36 DIM $(P=0.066)$ and a significant increase when mRNA levels in d 51 were compared with d $36(P<0.05$; Figure $1 \mathrm{C})$. In contrast to the results obtained with $G 6 P C$ and $P E P C K-C$ genes in both genetic groups, the results significantly differed when mRNA levels of the MUT gene were analyzed in both groups (Figure 2). Because all these genes encode key enzymes involved with glucose synthesis and the requirement of glucose increases due to a higher demand for milk production after calving, in agreement with these authors, we proposed that increased expression of G6PC, PEPCK-C, and MUT genes at the postpartum period is an indication of liver metabolic adaptation in response to the increased glucose demand. We observed elevated NEFA and BHB plasma concentrations at the same time, which may indicate negative regulation between the metabolites and the gene G6PC expression, for example (van Dorland et al., 2009; Weber et al., 2013a). According to Schaff et al. (2012) and Weber et al. (2013a), elevated levels of plasma concentration of NEFA and BHB during the postpartum period is related to high hepatic fat storage after calving, probably due to the NEB, which favored the expression of genes involved in the synthesis of fatty acids by the hepatic tissue. High fat storage might lead to metabolic disorders that can cause health and reproductive problems (Herdt, 2000; Ingvartsen and Andersen, 2000) and a reduction in the expression of genes involved with carbohydrate metabolism in the hepatic tissue of cows during transition period (Loor et al., 2005; Weber et al., 2013a). The reduced expression of G6PC, PEPCK$C$, and MUT genes observed at d 21 postpartum was in agreement with a condition of high fat storage. Interestingly, because we have detected higher levels of
mRNA of the MUT gene in $\mathrm{F}_{1}$ Holstein-Gir compared with Holstein cows (Figure 2), we might speculate that the energetic balance is more favorable in $F_{1}$ cows than in Holstein cows. According with this hypothesis, increased plasma concentration of glucose (Table 2), fat and protein content of milk (Supplemental Table S1; https://doi.org/10.3168/jds.2016-12459) were observed in $\mathrm{F}_{1}$ Holstein-Gir cows compared with Holstein cows, but additional studies are required to further investigate these differences. The main source of variation in the performance among cows, the nutrient partition capacity is important to provide nutrients or tissue reserves (or both) to the mammary gland or other tissues, to be used as energy sources (Baumgard et al., 2006). The MUT gene encodes the enzyme methylmalonyl-CoA mutase, which is essential for metabolic reactions and energy metabolism in ruminants hepatocyte because it catalyzes the conversion of propionate to succinate, which can enter the tricarboxylic acid cycle and be metabolized by the gluconeogenesis pathway (Le Grusse and Watier, 1993). Because the Glut2 transporter expressed in the liver is responsible for releasing glucose into the bloodstream (Zhao and Keating 2007), we also determined the mRNA levels of the SLC2A2 (Glut2) gene. However, similar to studies reported by Hammon et al. (2009), although we found a tendency toward increased expression of this gene at d 51 postpartum, no statistically significant differences in the expression of this gene throughout the postpartum period were observed $(P>0.05$; Supplemental Figure S1; https://doi .org/10.3168/jds.2016-12459). Except for the PEPCK$C$ gene, no interaction was observed between genetic groups and experimental period for the expression of G6PC, MUT, and SLC2A2 genes (Supplemental Table S3; https://doi.org/10.3168/jds.2016-12459).

\section{Expression of Genes Related to Fatty Acid Metabolism}

Gross et al. (2013) observed that expression levels of $A C C$ gene in the hepatic tissue increased after calving when comparing the first week of postpartum with $d$ 21 of prepartum in cows that consumed the same diet. Although we did not detect statistically differences in mRNA levels of the $A C C$ gene throughout the period analyzed, we observed a tendency toward increased gene expression at d 51 postpartum $(P=0.07$; Supplemental Figure S2A; https://doi.org/10.3168/jds.2016 -12459). Wolfrum and Spener (2000) suggest that it is possible that increased concentrations of NEFA and their CoA-esters might influence the $A C C$ gene activity. Based on our analyses, we cannot assume that NEFA has a direct effect in the control of mRNA levels of 
A

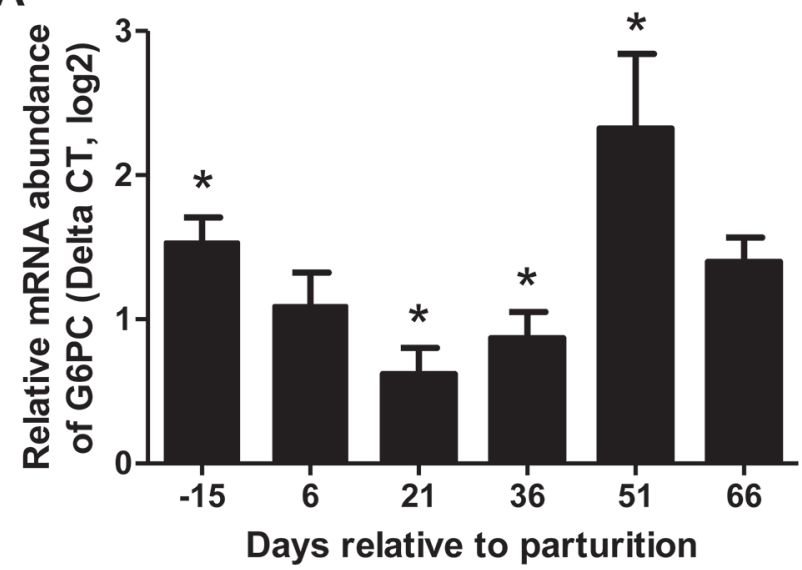

C

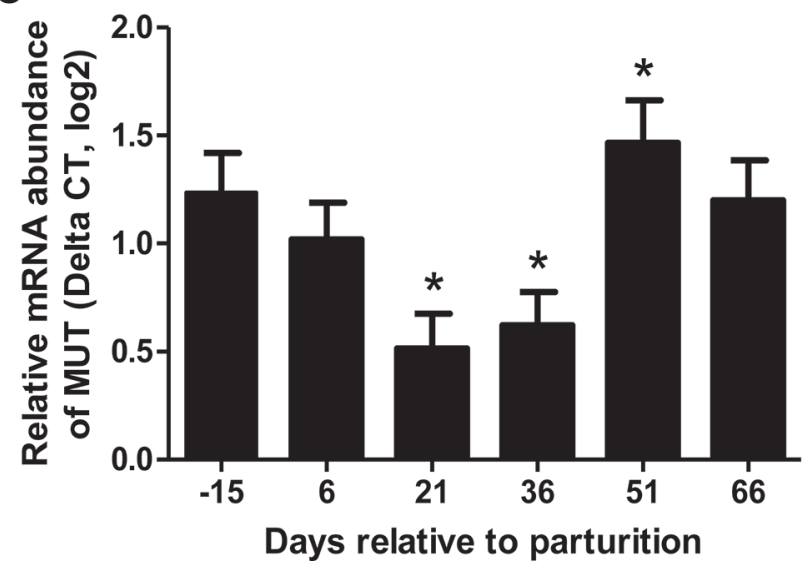

B

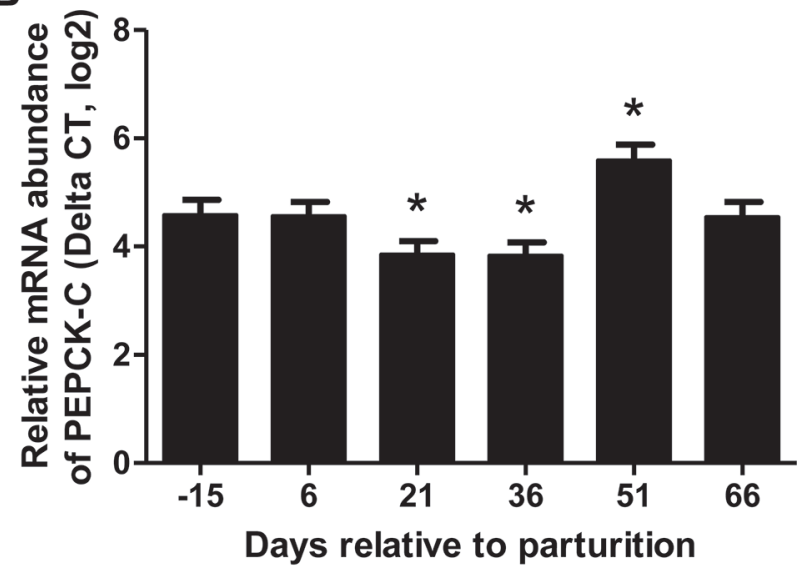

Figure 1. Average relative concentration of mRNA [delta cycle threshold $(\mathrm{CT}) / \log _{2}$ ] of the enzymes glucose-6-phosphatase $(G 6 P C$; A), cytosolic phosphoenolpyruvate carboxykinase (PEPCK-C; B), and methylmalonyl-CoA mutase (MUT; C) at -15, 6, 21, 36, 51, and 66 d relative to parturition of Holstein and $\mathrm{F}_{1}$ Holstein-Gir cows. ${ }^{*} P<0.05$. Error bars are SE of the LSM.

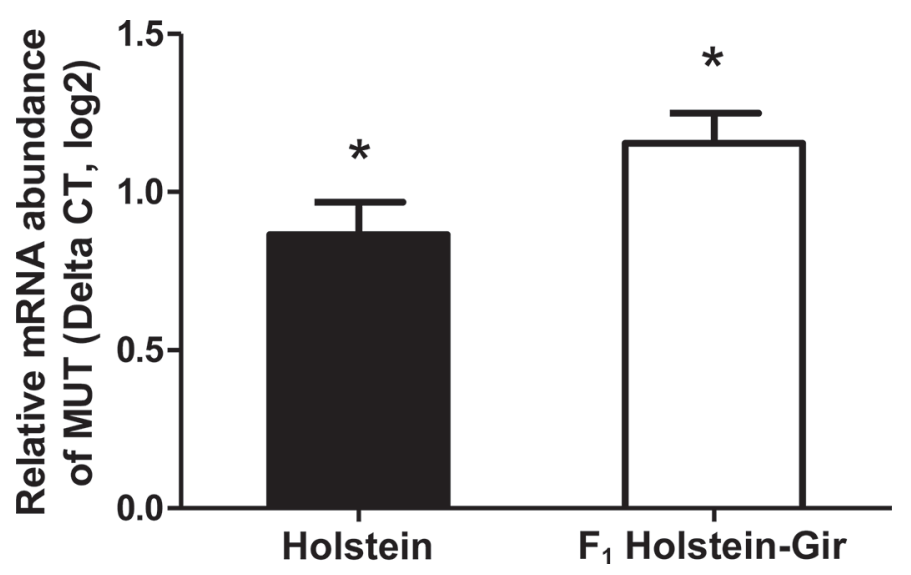

Figure 2. Average relative concentration of mRNA [delta cycle threshold (CT)/ $\log _{2}$ ] of the enzyme encoding methylmalonyl-CoA mutase gene $(M U T)$ between Holstein and $\mathrm{F}_{1}$ Holstein-Gir cows. ${ }^{*} P<$ 0.05. Error bars are SE of the LSM. the ACC gene during the period analyzed. Hormonal changes during that period might limit the animal ability to metabolize NEFA to triglycerides in the liver leading to accumulate of NEFA and its conversion of acetyl-CoA to ketone bodies, such as BHB. As shown on Table 2, we found increased concentration of BHB in plasma, after calving. Li et al. (2012) observed that the expression of genes coding the enzymes carnitine palmitoyltransferase I and II decreased in the hepatic tissue of ketotic cows. These authors also observed reduced expression of the transcription factor PPARA declined in the tissue of cows with elevated NEFA and BHB, due to fat accumulation (Loor et al., 2007; Weber et al., 2013a). The PPARA gene encodes a ligand-activated transcription factor involved in regulating hepatic gene expression related to glucose and fatty acid metabolism (Loor et al., 2007; White et al., 2011). Upregulated of the PPARA gene in response to NEFA concentra- 
tions may affect the expression of genes associated with ketogenesis (Murondoti et al., 2004; Loor et al., 2005). However, similarly to studies described by van Dorland et al. (2009), we found no differences in the levels of PPARA and CPT2 mRNA ( $P>0.05$; Supplemental Figure S2B-S2C; https://doi.org/10.3168/jds .2016-12459). Likewise, van Dorland et al. (2009) did not find any difference in the levels of PPARA mRNA when the BHB plasma concentration was higher than $0.750 \mathrm{mmol} / \mathrm{L}$. On the other hand, Li et al. (2013) reported reduced levels of $A C C$ and $C P T 2$ mRNA when plasma concentrations of NEFA and $\mathrm{BHB}$ were higher than 0.700 and $1.9 \mathrm{mmol} / \mathrm{L}$, respectively, during the postpartum period. Our analyses also showed that the expression of genes encoding the enzymes $A C C$ and CPT2 and the transcription factor PPARA did not differ between the analyzed genetic groups $(P>0.05)$, and there was no interaction between genetic groups and the experimental period $(P>0.05$; Supplemental Table S3; https://doi.org/10.3168/jds.2016-12459).

\section{Expression of Genes Related to Ketogenesis and Cholesterol Metabolism}

We analyzed the expression of genes encoding the enzymes HMGCR and BDH2 and showed that it did not differ between the genetic groups $(P>0.05)$ and there was no interaction between genetic groups and the experimental period ( $P>0.05$; Supplemental Table S3; https://doi.org/10.3168/jds.2016-12459). However, the gene expression of the HMGCR has a tendency to increase at d 51 when compared with the initial postpartum period and to d $66(P<0.05$; Figure S2D; https://doi.org/10.3168/jds.2016-12459). Changes in the expression of $H M G C R$ and $B D H 2$ genes during the transition period may affect cholesterol and ketone body synthesis, respectively (Graber et al., 2010; Schlegel et al., 2012). It is important to note that changes in protein abundance or enzyme activity may occur without a significant change in mRNA levels, due to variations in mRNA translation or due to protein posttranslational modifications (Penner et al., 2009). It should be also noted that, even though BHB concentrations reached $1.2 \mathrm{mmol} / \mathrm{L}$ at d 21 postpartum, we found no differences in the expression of BDH2. Contrary to the study described by $\mathrm{Xu}$ et al. (2008), the cows in our study did not show any signs of ketosis (Supplemental Figure S2E; https://doi.org/10.3168/jds.2016-12459). Ketosis is a major metabolic disorder of dairy cows in early lactation and is characterized by a relatively high concentration of the ketone bodies, such as acetoacetate or BHB, and low blood glucose concentration (Grummer, 1995; Duffield et al., 2008).

\section{CONCLUSIONS}

Gene expression analyses in 2 groups of cows, Holstein cows and $F_{1}$ Holstein-Gir, during the periparturient period indicated that most genes involved in glucose and fatty acid metabolisms in the liver have similar expression profiles. We showed that, in both groups of cows, expression of genes encoding key enzymes of the gluconeogenesis pathway decreased after calving. At the same time, NEFA and BHB plasma concentrations increased in the postpartum compared with the prepartum period in both groups of animals. Expression of the MUT gene also decreased during the postpartum when compared with prepartum, but was increased at d 51 when compared with 21 and 36 DIM. Because expression of the $M U T$ gene was higher in $\mathrm{F}_{1}$ Holstein-Gir than in Holstein cows, we tend to speculate that the energetic balance is more favorable in $\mathrm{F}_{1}$ cows than in Holstein cows, because this gene encodes an enzyme responsible for the conversion of propionate to succinate, an essential reaction of the metabolism in ruminant hepatocytes. $F_{1}$ Holstein-Gir also had higher plasma glucose concentrations, fat, and protein content in milk than Holstein cows, even though milk production in Holstein was higher than in $\mathrm{F}_{1}$ Holstein-Gir cows. Thus, to fully understand the molecular factors determining the differences in energy metabolism and milk performance observed between the 2 groups of cows, further studies are necessary, including a more deep investigation of the elements controlling MUT gene expression. Moreover, it would be important to investigate the consequences of the differential expression of the MUT gene on the intermediary metabolism of Holstein and $\mathrm{F}_{1}$ Holstein-Gir cows.

\section{ACKNOWLEDGMENTS}

The authors gratefully acknowledge the FAPEMIG for funding the Project APQ-00558-13, and Higher Education Personnel Improvement Coordination (CAPES), and experimental farm Hélio Barbosa/ Minas Gerais-Brazil, and Laboratory of Genomics and Molecular Genetics of Parasites (ICB-UFMG), and Pathology Laboratory of the Veterinary School, and Department of clinical and surgery of the Veterinary School. The study was supported by Federal University of Minas Gerais, Brazil.

\section{REFERENCES}

Alam, T., D. A. Kenny, T. Sweeney, F. Buckley, M. Prendiville, R. McGee, and S. M. Waters. 2012. Expression of genes involved in energy homeostasis in the duodenum and liver of Holstein-Friesian and Jersey cows and their $\mathrm{F}_{1}$ hybrid. Physiol. Genomics 44:198-209. 
Alves, B. G., K. A. Alves, M. C. Martins, L. S. Braga, T. H. Silva, B. G. Alves, R. M. Santos, T. V. Silva, M. A. O. Viu, M. E. Beletti, J. O. Jacomini, and M. L. Gambarini. 2014. Metabolic profile of serum and follicular fluid from postpartum dairy cows during the summer and winter. Reprod. Fertil. Dev. 26:866-874.

AOAC. 1990. Official Methods of Analysis of the Association of Official Analytical Chemists. 15th ed. Association of Official Analytical Chemists, Washington, DC.

Bauman, D. E., and W. B. Currie. 1980. Partitioning of nutrients during pregnancy and lactation; A review of mechanisms involving homeostasis and homeorhesis. J. Dairy Sci. 63:1514-1529.

Baumgard, L. H., L. J. Odens, J. K. Kay, R. P. Rhoads, M. J. Van Baale, and R. J. Collier. 2006. Does Negative Energy Balance limit milk synthesis in early lactation. Pages $181-187$ in 21st Annual Southwest Nutrition and Management Conference. Proceedings. February 23-24, 2006, Tempe, AZ.

Bell, A. W. 1995. Regulation of organic nutrient metabolism during transition from late pregnancy to early lactation. J. Anim. Sci. 73:2804-2819.

Bergman, E. N. 1971. Hyperketonemia-Ketogenesis and ketone body metabolism. J. Dairy Sci. 54:936-948.

Bobe, G., J. W. Young, and D. C. Beitz. 2004. Pathology, etiology, prevention, and treatment of fatty liver in dairy cows. J. Dairy Sci. 87:3105-3124.

Doepel, L., H. Lapierre, and J. J. Kennelly. 2002. Performance and metabolism of dairy cows in response to prepartum energy and protein intake. J. Dairy Sci. 85:2315-2334.

Drackley, J. K. 1999. Biology of dairy cows during the transition period: The final frontier. J. Dairy Sci. 82:2259-2273.

Duffield, T. F., A. R. Rabiee, and I. J. Lean. 2008. A meta-analysis of the impact of monensin in lactating dairy cattle. Part 1. Metabolic effects. J. Dairy Sci. 91:1334-1346.

Emery, R. S., J. S. Liesman, and T. H. Herdt. 1992. Metabolism of long chain fatty acids by ruminant liver. J. Nutr. 122:832-837.

Fulkerson, W. J., T. M. Davison, S. C. Garcia, G. Hough, M. E. Goddard, R. Dobos, and M. Blockey. 2008. Holstein-Friesian dairy cows under a predominantly grazing system: Interaction between genotype and environment. J. Dairy Sci. 91:826-839.

Goff, J. P., and R. L. Horst. 1997. Physiological changes at parturition and their relationship to metabolic disorders. J. Dairy Sci. 80:1260-1268

Graber, M., S. Kohler, T. Kaufmann, M. G. Doherr, R. M. Bruckmaier, and H. A. Van Dorland. 2010. A field study on characteristics and diversity of gene expression in the liver of dairy cows during the transition period. J. Dairy Sci. 93:5200-5215.

Gross, J. J., F. J. Schwarz, K. Eder, H. A. Van Dorland, and M. B. Bruckmaier. 2013. Liver fat content and lipid metabolism in dairy cows during early lactation and during a mid-lactation feed restriction. J. Dairy Sci. 96:5008-5017.

Grummer, R. R. 1993. Etiology of lipid-related metabolic disorders in periparturient dairy cows. J. Dairy Sci. 76:3882-3896.

Grummer, R. R. 1995. Impact of changes in organic nutrient metabolism on feeding the transition dairy cow. J. Anim. Sci. 73:28202833.

Hammon, H. M., S. N. Sauter, M. Reist, Y. Zbinden, C. Philipona, C. Morel, and J. W. Blum. 2003. Dexamethasone and colostrums feeding affect hepatic gluconeogenic enzymes differently in neonatal calves. J. Anim. Sci. 81:3095-3106.

Hammon, H. M., F. Sturner, A. Schneider, H. Tuchscherer, T. Blum, A. Engellard, R. Genzel, W. Staufenbiel, and W. Kaniz. 2009. Performance and metabolic and endocrine changes with emphasis on glucose metabolism in high-yielding dairy cows with high and low fat content in liver after calving. J. Dairy Sci. 92:1554-1566.

Hansen, J. V., N. C. Friggens, and S. Hojsgaard. 2006. The influence of breed and parity on milk yield and milk yield acceleration curves. Livest. Sci. 104:53-62.

Herdt, T. H. 2000. Ruminant adaptation to negative energy balance: Influences on the etiology of ketosis and fatty liver. Vet. Clin. North Am. Food Anim. Pract. 16:215-230.
Ingvartsen, K. L., and J. B. Andersen. 2000. Integration of metabolism and intake-regulation: A review focusing on periparturient animals. J. Dairy Sci. 83:1573-1597.

Kreipe, L., M. C. M. B. Vernay, A. Oppliger, O. Wellnitz, R. M. Bruckmaier, and H. A. Van Dorland. 2011. Induced hypoglycemia for 48 hours indicates differential glucose and insulin effects on liver metabolism in dairy cows. J. Dairy Sci. 94:5435-5448.

Le Grusse, J., and B. Watier. 1993. Les vitamines. Données biochimiques, nutritionnelles et cliniques. Centre d'étude et d'information sur les vitamines, Produits Roche, Neuilly-sur-Seine, France.

Li, P. X. Li, S. X. Fu, C. C. Wu, X. X. Wang, G. J. Yu, M. Long, Z. Wang, and G. W. Liu. 2012. Alterations of fatty acid $\beta$-oxidation capability in the liver of ketotic cows. J. Dairy Sci. 95:1759-1766.

Li, P., C. C. Wu, M. Long, Y. Zhang, X. B. Li, J. B. He, Z. Wang, and G. W. Liu. 2013. Short communication: High insulin concentrations inhibit fatty acid oxidation-related gene expression in calf hepatocytes cultured in vitro. J. Dairy Sci. 96:3840-3844.

Loor, J. J. 2010. Genomics of metabolic adaptations in the peripartal cow. Animal 4:1110-1139.

Loor, J. J., H. M. Dann, R. E. Everts, R. Oliveira, C. A. Green, N. A. Janovick-guretzky, S. L. Rodriguez-zas, H. A. Lewin, and J. K. Drackley. 2005. Temporal gene expression profiling of liver from periparturient dairy cows reveals complex adaptive mechanisms in hepatic function. Physiol. Genomics 23:217-226.

Loor, J. J., R. R. Everts, M. Bionaz, H. M. Dann, D. E. Morin, R. Oliveira, S. L. Rodriguez-zas, J. K. Drackley, and H. A. Lewin. 2007. Nutrition-induced ketosis alters metabolic and signaling gene networks in the liver of peripartirient dairy cows. Physiol. Genomics 32:105-116.

Mann, S., F. A. Leal Yepes, M. Duplessis, J. J. Wakshlag, T. R. Overton, B. P. Cummings, and D. V. Nydam. 2016. Dry period plane of energy: Effects on glucose tolerance in transition period cows. J. Dairy Sci. 99:701-717.

McCarthy, S. D., S. M. Waters, D. A. Kenny, M. G. Diskin, R. Fitzpatrick, J. Patton, D. C. Wathers, and D. G. Morris. 2010. Negative energy balance and hepatic gene expression patterns in highyielding dairy cows during the early postpartum period: A global approach. Physiol. Genomics 42A:188-199.

Moreira, T. F., E. J. Facury Filho, R. M. Meneses, J. A. M. Lima, and A. U. Carvalho. 2015. Energetic status of crossbreed dairy cows during transition period in two different seasons. Arq. Bras. Med. Vet. Zootec. 67:1327-1334.

Murondoti, A., R. Jorritsma, A. C. Beynen, T. Wensing, and M. J. H. Geelen. 2004. Unrestricted feed intake during the dry period impairs the postpartum oxidation and synthesis of fatty acids in the liver of dairy cows. J. Dairy Sci. 87:672-679.

NRC. 2001. Nutrient Requirements of Dairy Cattle. 7th rev. ed. Natl. Acad. Press, Washington, DC.

Penner, G. B., M. Taniguchi, L. L. Guan, K. A. Beauchemin, and M. Oba. 2009. Effect of dietary forage to concentrate ratio on volatile fatty acid absorption and the expression of genes related to volatile fatty acid absorption and metabolism in ruminal tissue. J. Dairy Sci. 92:2767-2781.

Reid, I. M., and R. A. Collins. 1980. The pathology of postparturient fatty liver in high-yielding dairy cows. Invest. Cell Pathol. $3: 237-249$.

Santos, S. A., S. C. Valadares Filho, E. Detmann, R. F. D. Valadares, J. R. M. Ruas, and P. M. Amaral. 2012. Voluntary intake and milk production in $\mathrm{F}_{1}$ Holstein X Zebu cows in confinement. Trop. Anim. Health Prod. 44:1303-1310.

Schaff, C., S. Borner, S. Hacke, U. Kautzsch, D. Albrecht, H. M. Hammon, M. Rontgen, and B. Kuhla. 2012. Increased anaplerosis, TCA cycling and oxidative phosphorylation in the liver of dairy cows with intensive body fat mobilization during early lactation. J. Proteome Res. 11:5503-5514.

Schlegel, G. S., R. Ringseis, W. Windisch, F. J. Schwarz, and K. Eder. 2012. Effects of a rumen-protected mixture of conjugated linoleic acids on hepatic expression of genes involved in lipid metabolism in dairy cows. J. Dairy Sci. 95:3905-3918. 
Sofyan, A., M. Mitsumori, H. Ohmori, Y. Uyeno, T. Hasunama, K. Akiyama, H. Yamamoto, H. Yokokawa, T. Yamaguchi, T. Shinkai, M. Hirako, and S. Kushibiki. 2017. Differences in rumen fermentation characteristics between low-yield and high-yield dairy cows in early lactation. Anim. Sci. J. 88:974-982. https://doi.org/10 $.1111 /$ asj.12745.

van Dorland, H. A., S. Richter, I. Morel, M. G. Doherr, N. Castro, and R. M. Bruckmaier. 2009. Variation in hepatic regulation of metabolism during the dry period and in early lactation in dairy cows. J. Dairy Sci. 92:1924-1940.

Van Soest, P. J., J. B. Robertson, and B. A. S. Lewis. 1991. Methods for dietary fiber, neutral detergent fiber, and non-starch polysaccharides in relation to animal nutrition. J. Dairy Sci. 74:3583-3597.

Weber, C., C. Hametner, T. Tuchscherer, B. Losand, E. Kanitz, W Otten, H. Sauerwein, R. M. Bruckmaier, F. Becker, W. K. Anitz, and H. M. Hammon. 2013a. Hepatic gene expression involved in glucose and lipid metabolism in transition cows: Effects of fat mobilization during early lactation in relation to milk performance and metabolic changes. J. Dairy Sci. 96:5670-5681.

Weber, C., C. H. Hametner, A. Tuchscherer, B. Losand, E. Kanitz, W. Otten, S. P. Singh, R. M. B. Bruckmaier, F. Becker, W. Kanitz, and H. M. Hammon. 2013b. Variation in fat mobilization during early lactation differently affects feed intake, body condition, and lipid and glucose metabolism in high-yielding dairy cows. J. Dairy Sci. 96:165-180.

White, H. M., E. R. Carvalho, S. L. Koser, N. S. Schmelz-Roberts, L. M. Pezzanite, A. C. Slabaugh, P. H. Doane, and S. S. Donkin. 2016. Short communication: Regulation of hepatic gluconeogenic enzymes by dietary glycerol in transition dairy cows. J. Dairy Sci. 99:812-817.

White, H. M., S. L. Koser, and S. S. Donkin. 2011. Differential regulation of bovine pyruvate carboxylase promoters by fatty acids and peroxisome proliferator-activated receptor- $\alpha$ agonist. J. Dairy Sci. 94:3428-3436

Wolfrum, C., and F. Spener. 2000. Fatty acids as regulators of lipid metabolism. Eur. J. Lipid Sci. Technol. 102:746-762.

Xu, C., Z. Wang, G. Liu, X. Li, G. Xie, C. Xia, and H. Zhang. 2008. Metabolic characteristic of the liver of dairy cows during ketosis based on comparative proteomics. Asian-australas. J. Anim. Sci. 21:1003-1010.

Zhang, Q., S. L. Koser, B. J. B. Bequette, and S. S. Donkin. 2015. Effect of propionate on mRNA expression of key genes for gluconeogenesis in liver of dairy cattle. J. Dairy Sci. 98:8698-8709.

Zhao, F. Q., and A. F. Keating. 2007. Functional properties and genomics of glucose transporters. Curr. Genomics 8:113-128. 